\title{
情報コミュニケーションの今後と情報技術の役割
}

\section{The Future of Communication, The Role of Information}

\author{
Technology \\ 中川修* \\ Osamu NAKAGAWA*
}

*大日本印刷株式会社

ICT Business Development Division, Advanced Business Center, Dai Nippon Printing Co., Ltd.

干162-8001 東京都新宿区市谷加賀町1-1-1

E-mail: nakagawa-o@mail.dnp.co.jp

\section{1 はじめに}

まず，情報コミュニケーションのこれま での30年を振り返る. 何と言っても最初に World Wide Web（Web）である. CERN（欧 州原子核研究機構）の技術者であったTim Berners-Leeがその仕組みを提案したのが 1989年. これがその後の情報通信の世界を 決定的に変えたと言っても過言ではない. 1995年, Windows95の発売とともに認知さ れたWebブラウザの登場によって，そのWeb を通したコミュニケーションが一気に普 及する，世紀末の1999年には，i-modeサー ビスが開始され，携帯端末でのコミュニケ ーションが特別なものではなくなり，2000 年代前半にはソーシャルメディアによっ て，個人が情報発信の主体になり得る時代 となった。2000年代後半からは，iPhoneを はじめとするスマホやタブレットの登場 により，さらに情報コミュニケーションの 世界は一変する。いまや, 通勤電車で紙の 新聞や雑誌を読んでいる人は本当に少数 派になったし，もはや後戻りできないくら
いに，スマホは生活に密着したメディアに なっている.

本稿では，このような情報コミュニケー ションの進展によって，どんな社会的な変 化が起きたのか，あるいは，起きつつある のかを概観しながら，今後の30年に向け情 報技術（とりわけ情報知識学）に期待され る役割について考えてみたい.

\section{2 技術進化が牽引する社会変化}

\section{1 これまで}

これまでの 30 年における情報コミュニケ ーションの進化を大きく 3 つに整理する. (1) いつでも, どこでも情報アクセス

従来, 時事ニュース, 教養, 娛楽, 趣味に 関わる情報, 知識は, 新聞, 杂誌誌, テレビ, ラ ジオを通して得たり, あるいは書籍購入や図 書館を利用するといった形で取得していた. Webの登場によって, 情報はデジタル化され ネットワークを介して流通し, さらには, 携帯電 話, スマホの登場によって, いつでも, どこで 
も，気軽にあらゆる情報に触れられるようにな った.

\section{（2）個人による情報発信, 個人のメディア化}

従来，自分が得た情報や創作したコンテン ツを公の場に発信・発表することは, 新聞, 雑 誌, テレビ, ラジオといった媒体を通して行うし かなく, 記事を書く専門技能や創作の才能を もった一部の人にしかできないある種の特権 であった. ネットワーク技術の進展によって, Webでのコミュニケーションが非常に安価に行 えるようなり, 同時に登場してきたソーシャルメ ディアを通して, 個人同士のコミュニケーショ ンは爆発的に増大した. そして, 現在, 極めて 大きな社会的影響を及ぼす一大メディアにま で成長している。

\section{（3）欲しい情報がすぐに簡単に入手可能}

ネットワーク上に流通する情報量が急速に 増大寸る中，それと歩調を合わせる形で検索 サービスの重要性が高まり, 今ではネットでの 情報アクセスのたびにお世話にならざるを得 ない, 絶対になくてはならないサービスとなっ ている. 音声インターフェースや自然言語検 索などによって検索キー入力のストレスを軽 減したり、ユーザーの趣味・啫好や意図を把 握して、欲しい情報を先回りして提示するよう な技術についても日進月歩である。

これら情報コミュニケションの変化に伴って， 起きた社会的な変化として，まず, 30年前に はほぼ影も形もなかった企業群の台頭がある. GAFA (Google,Apple,Facebook,Amazon) と略 される企業がその代表例である. ネットでの情 報コミュニケーションを前提とした新しいビジ ネスモデル $=W e b$ 広告媒体 (検索, SNS) や才 ンラインショッピング, 新しい携帯端末などを ベースに情報プラットフォームをオープンにし ながら, うまく自社中心のエコシステムを構築
し成功している. また, AirbnbやUberに代表さ れる, シェアリングエコハーと呼ばれる新たな 市場経済が大きく成長しようとしている. その 本質は, 個人が保有している遊休資産の貸出 を仲介するサービスであり，上述の情報コミュ ニケーションの変化がなければ, 決して実現さ れ得ないサービス形態である. 無人店舗やキ ヤツシュレス化といったビジネス形態も情報コミ ユニケーション技術の進展により実現した新た な動きと言える.おそらく 30 年前の常識的な人 類が見たら信じ難い未来のスマート社会に 我々は寸でに住んでいるのだ, といらと言い 過ぎだろうか.

\section{2 これから}

さて，これまでの変化が，人間同士の多 様なつながりによって引き起こされた社 会的イノベーションであると（単純化しす ぎかもしれないが…) 言ってしまうとする と, 今後の変化は, 果たして何によって引 き起こされるのであろうか。結論から言う と, 近年目覚ましい発展を遂げている人工 知能（AI）技術によって実現される「人間 の知的活動の（一部）代替」が, 変化の大 きな原動力になるのではないかと考えて

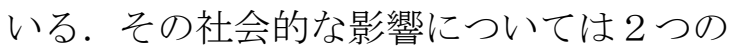
側面がある。一つはポジティブ，もう一つ はネガティブな側面である.

まず,ポジティブな側面から.日本では, 少子高齢化を背景とした労働人口の減少 は国家的な課題となっている. と同時に， 製造業・サービス業をはじめ労働生産性が 先進各国と比較して低いという現状もあ る．解決する手段として，これまで自動化 が難しかった，知的雑務をAIに代行させる ということが期待されており，機械の異常 検知や警備・監視といった領域や顧客対応 
における定型応答の自動化といった領域 など，各所でAIの応用が進められている. その延長方向には，面倒な作業を機械で代 替し，人間にしかできないクリエイティブ な仕事のみを実行することで，「生活のた めの労働」から「自己実現のための労働」 への脱却という，明るい未来の実現がある。

一方，ネガティブな側面である。「AIに よって仕事が奪われる」という議論がその 代表例である. 大きな技術革新のたびに歴 史上人類が何度も経験し乗り越えてきた 事象ではあるが，個人個人や個別企業の問 題としては現実的に切実であるので, 移行 のストレスをいかに極小化するかという 施策は重要である。ややSF的ではあるが， $\mathrm{AI}$ の暴走をどう食い止めるか, AIが出した 答えの意味がわからなくても正しければ 無批判に従う人類社会はそれで良いのか 等々，AIに支配されるディストピアを想像 しながら，AI開発やめるべしという極論も ある。

\section{3 情報技術の役割}

これらの変化を踏まえ，今後情報技術 (とりわけ情報知識学) に期待される役 割は何であろうか. 2 つ視点から考え てみたい。

まず一つ目．最近のディープラーニン グや強化学習の技術進化には目を見張る ものがあるのは確かである。しかし，人 間の知的な活動を代替する AI の登場に は，まだ何段階もの技術的なブレークス ルーが必要である。ディストピアを想像 し暗澹とする前に，ポジティブ面をさら に押し進め進歩させる余地も必要もある と考える. 現在の AI は, 人間の認知機能
の代替という意味では大きな進歩を遂げ たが，言語理解やコミュニケーションの 代替という意味では，まだまだ未熟であ る. その方向へ AI 技術を大きく進歩させ るためには，情報から知識を抽出して構 造化し，それを活用するための技術が是 非とも必要となる。まさに，情報知識学 が目指してきた研究の方向であろう.

次に 2 つ目。とは言いつつ, 遠い将来 かもしれないが，人間を代替する汎用的 な AI の実現により, 人類がこれまで経験 してこなかった状況に陥る可能性はある。 そうなったとき必要になるのは, 科学者 の理論でも技術者の生み出寸技術でもな い. 人間や社会の本質やあり方について 深く追求してきた, 哲学や社会学といっ た人文的な知ではないか。 そして，その 人文知をいかにして人類共有のものにし ていけるか，そこに情報技術，とりわけ 情報知識学が貢献できるのではないかと 考える。

$$
\text { グーテンベルクが起こした情報革命 }
$$
（=知の民主化）の精神の上で，長年事 業を行ってきた一企業に所属する一技術 者として，ほんのわずかでも，それに対 して貢献できればと思う。 